\title{
Global Issues of Higher Education with SPeCial ReFERENCE to LATin AMERica AND THE CARIBBEAN ${ }^{1}$
}

\author{
Francisco López Segrera ${ }^{a}$ \\ Technical University of Catalonia
}

\begin{abstract}
Higher education in Latin America has deep roots back to the Spanish colonisation in the Hispanic countries. In Brazil, a former Portuguese colony, this sector did not emerge until the nineteenth century and in the Anglophone Caribbean, not until the twentieth. Now in the twenty-first century throughout the region it is subject to the global reach of the neoliberal era with marketisation, quality assurance and international rankings playing very strong roles. The number of private higher education institutions has increased dramatically with problems attached for quality, which is extremely variable. New types of institution have emerged, for example the community colleges in the Anglophone Caribbean offering the first few years of undergraduate study even in small island nations. At the top of the scale there are still quality institutions, but they are locked into the global convention and competition of the international rankings and league tables. So the overall picture is of a higher education sector of unusual variety and variability.
\end{abstract}

KEYWORDS: universities, globalisation, accreditation, international rankings, Latin America, Caribbean

\section{Introduction}

Universities worldwide are facing the influences of globalisation, which can be both positive and negative. Either way, greater challenges arise. In this new context, university traditional values (autonomy, academic freedom, objective research, teaching and assessment) must still be valid, but they should be mediated through the lens of global education. This will be discussed in general, and then a focus on the regions of Latin America and the Caribbean will follow.

Globalisation is an irreversible and dynamic phenomenon affecting education. It makes no sense to ignore it. Instead, what we should be concerned with is the type of globalisation that should prevail. In a university context, should we merely accept the most negative and more visible aspects of globalisation, or should we seriously devote ourselves to the construction of a global society that responds to more justice and solidarity, and to human and social development?

The objective of analysing these comprehensive issues here is to contribute to the promotion of necessary transformations among higher education institutions (HEI). This sector is experiencing a set of transformations in its institutions namely:
a) Massification;
b) Horizontal and Vertical Differentiation;
c) Quality Assurance and Accreditation;
d) Increasing Demand for Specific Knowledge;
e) Diversification and Rationalisation of Funding;
f) The Acceptance of Entrepreneurial Cultures;
g) Gravitation from the State to the Market (Brunner, 2005, pp 3-4).

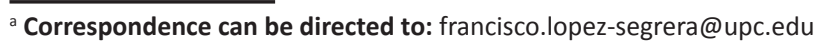


These, together with 'brain drain', mean that universities in all countries have to respond simultaneously at a number of levels: local, national, regional and global. In the documents of the The World Conference on Higher Education summoned by UNESCO (2009), a number of valuable suggestions were made relating to the most urgent challenges. These included: a) the regular upgrading of the teaching staff and content; b) the further extension of electronic networks for learning; c) translation and internationalisation and of the main scientific contributions; $d$ ) management modernisation; e) the complementation of public and private education; $f$ ) also of informal and distance education; and additionally, as discussed by Alexiadou and Brock (1996), higher education (HE) should be considered as a public good and not just a commodity.

\section{Higher Education Today: Global Trends and Challenges}

Enrolment in higher education institutions has increased massively from 13 million in 1960 to well over 20 million today (UNESCO, 2011). This has been accompanied by an increase of academic international mobility which has resulted to the rise of privatisation of higher education in many parts of the world. Only in Western Europe is higher education financed mainly by the State, and this is changing in some countries by stealth, as exemplified by the new fees regime for undergraduate students in England. Even in the poorest region, the Sub-Saharan Africa, private 'universities' are increasingly common and often, as elsewhere, of very questionable quality (Pillay, 2010).

Inequity in access is also massive, based on a range of factors, including race, gender, ethnicity, religious, and social class. Together they continue to deprive many with sufficient merit and potential to undertake university studies. In Brazil in 2008, for example, of five quintiles, $74 \%$ of the students in universities belong to the highest social quintile and only $4 \%$ to the lowest quintile (CEPAL, 2008), whereas the real human potential of the country is much more widely spread. Management Quality and Policy is another area of concern. Despite some positivity it has been overshadowed by overbureaucratisation as its characteristics. In some cases, questionable management procedures have been used as a pretext to accelerate processes of privatisation, or reduction of state funding to higher education, for purposes of personal financial gain.

In addition, curriculum development in much of higher education, for undergraduate as well as post-graduate courses, has not progressed sufficiently to reflect the rapid changes and challenges at both national and international level. Consequently, there is a growing divergence in standards between universities, and other HEls across almost every country. This in turn works against the equivalence of qualifications that is one of the main objectives of UNESCO higher educational policy. Instead, what is happening is an increasing diversity (and a widening of the gap) in quality between the best, the average, and the worst.

Another of the negative consequence of economic globalisation and privatising trends in $\mathrm{HE}$ is the desire of the World Trade Organization to include tertiary education as a service within the regulations known as the General Agreement on Trade in Service (GATS). Though this offer may still be in the discussion stage, countries are divided on it (Sauve, 2002). Some of those that obtain important earnings from higher education, including international student enrolment, have strongly expressed their support for this initiative. It is of course a feature of the global dominance of neoliberal economics, but is related to a more constraining factor, that of accreditation. This can also be a questionable process. Many of the agencies involved do not know, or understand the values and needs of autochthonous development, and the whole procedure becomes invalid.

The rankings of universities worldwide has also become increasingly fashionable. In the mid1980s, the Asian Wall Street Journal had included only 4 non-US Universities (Cambridge, Oxford, Sorbonne, and Tokyo) in a list of supposedly top 10 universities worldwide (Altbach, 2004). Such rankings are highly partial, and its reliability questionable. Only those of the Times Higher Education Supplement (THES), and the Shanghai Jiao Tong University's (SJTU) rankings are regarded as valid nowadays, but even the latter is of limited use because it deals strictly with research, and based on very limited criteria. The rankings are constructed on the basis of two major indices - the number 
of Nobel Prizes, and teachers of the university with works in certain American based citation indices. Both THES and SJTU rankings are based on the use of English language, which favours the AngloSaxon world, especially of USA, UK, and Australia. They also favour the sciences and technologies to the detriment of the social sciences and humanities - where research grant is hard to obtain. Yet, to apply the procedure and values of only the principal academic powers operating in English will obviously be meaningless in a global context. This, of course, also relates to the aforementioned issue of global equivalence and recognition of qualifications. Especially in the less developed countries, instead of chasing indicators often difficult to reach in their specific conditions, more attention should be given to the ideal of universities that promote forms of sustainable development that are relevant and achievable in their own context (Altbach, 2006; Ordorika, 2008).

Evaluation and accreditation procedures offer more significant information about universities and other HEls. They pose a challenge against assaults dealt to the conception of HEls as being a public good. Such procedures of evaluation and accreditation can, through the careful and professional efforts of international organisations such as UNESCO, the Global Universities Network for Innovation (GUNI) and the United Nations University, potentially unlock the role of higher education in enhancing the achievement of sustainable survival in the twenty-first century. Additionally, they serve as a challenge against academic corruption through its potential of being subjected to political and economic pressures.

Unfortunately, universities and HEls are shaped by Nation-State policies, as much as by the global trends based on the capitalist system. These politico-economic influences on them are much more powerful than the changes and transformations that they can produce within themselves, and the society wherein they are embedded. Universities originated as international phenomena as their title implies (Brock, 2007). This leads us to ask ourselves: Is a fundamental transformation of the university possible without previous transformation from the predominance of the scale of the nation-state to the international or global scales? The internationalisation of universities is a key component of this debate (Brock, 2012).

\section{Main Trends of Higher Education in Latin America and the Caribbean}

\section{Latin America}

America, that is to say the 'New World' comprises the land areas of the continents of North America and South America, and the isthmus of Central America. In addition there are the islands of the Gulf of Mexico, the Caribbean Sea and nearby areas of the Atlantic Ocean. That is to do with physical geography, but the 'New World' exhibits three main components of cultural geography: 'Latin America' (predominantly Portuguese and Spanish speaking); Anglo-America (predominantly English speaking) and Franco-America (predominantly French Speaking). There are also many indigenous (Amerindian) languages and some small areas of Dutch speaking in Suriname and the Netherlands Antilles. Latin America comprises all of South and Central America except Belize, Guyana and Suriname, plus the Caribbean nations of Cuba and The Dominican Republic).

Before the 1980s, public tertiary education with institutional and academic autonomy had prevailed over private higher education in the region. However, at the end of the 1980s and early 1990s, globalisation occurred; meaning that the spread of neoliberal economic strategies began. These market-oriented strategies contributed to the increase of privatisation among the tertiary sector of education, and the consequent deterioration of public universities. This was due, in part, to the lack of appropriate public funding. In spite of this, during the 1990s, overall higher education in the region blossomed (García-Guadilla, 2006).

Higher education reforms in Latin America and the Caribbean in the last two decades have been oriented towards the satisfaction of an increasing demand fuelled by World Bank policies, and to a much lesser degree, the policies recommended by UNESCO in the aforementioned World Council on Higher Education (WCHE) in Paris in 1988. These transformations are in reality, mainly 
counter-reforms and not the type of reform needed in the various national public university sectors. According to Mollis (2003), the main traits of these transformations are as illustrated in Box 1 .

\section{Box 1 Transformations of Tertiary Education in Latin America}

- Diversification of HEls (university colleges, university institutes, short cycles with certificates and intermediate titles in the university level, new tertiary private institutions, among others).

- Diversified sources of funds (registration, sales of services) introduced as alternatives to the State financing.

- Strategic alliances among international agencies and governmental decision makers were formed.

- New alliances between universities, corporations, and the public sector were also established through:

Increasing presence of private investment in the offering of higher education through, new providers not controlled by State policies.

- Evaluation, accountability, accreditation and certification of programmes.

- Institutional and normative reforms of higher education laws.

- Policies of faculty differentiation through policies of incentives, according to indicators of productivity.

- Academic Reforms: shortening of careers, intermediate degrees, flexible curricula toward credit modality, and import of educational models based on the "acquisition of professional competitions".

- Predominance of distance learning (virtual university), remote tutorship, certification of knowledge and skills, and recycling of competencies.

Let us examine these prevailing trends (as well as others) in higher education in Latin America and the Caribbean between 1990 and 2008 in greater detail. The HEls increased from 5,438 in 1995 (53.7\% private) to 7,514 in 2002 (69.2\% private) (Garcia Guadilla, 2006, p.261), while enrolment in HEls had increased from 267,000 in 1950 to 19, 658,000 in 2009 (UNESCO, 2011). In 2003, the average amount of matriculation in tertiary education in private institutions was $50 \%$, with the percentage being greater in some countries such as: Brazil and Chile at $70 \%$, Colombia at $60 \%$, and Central America at about 60\%. For Mexico, Argentina, Uruguay, and Cuba, it is $40 \%, 20 \%, 10 \%$, and no change respectively (UNESCO IESALC, 2006; Fernandez Lamarra, 2008).

The mega-higher education systems (HES) in Brazil has over five million students $(5,273,000)$, while Mexico and Argentina have over two million. The medium higher education systems in Chile, Colombia, Peru, and Venezuela have between 500,000 and 1,200,000 students. There are also small higher education systems in Bolivia, Cuba, Ecuador, Guatemala, and Dominican Republic with student figures ranging between 150,000 and 500,000. Lastly, very small higher education systems in the case of Central America and the Anglophone and Francophone Caribbean countries where the amount of students ranges between 150,000 and 500,000 (UNESCO Institute of Statistics, 2009).

The gross enrolment rate (GER) varies from a range between $79 \%$ and $62 \%$ (Argentina and Cuba) to $20 \%$ (Honduras), while the average GER has risen from $17 \%$ at the beginning of the 1990 s to $43 \%$ by 2012 . However, in Latin America and the Caribbean, expenditures per student ( 2380 US Dollars) are comparatively lower than in other developed countries, and private expenditure finances $50 \%$ of the total enrolment (UNESCO Institute of Statistics, 2014).

The most rapid expansion is in pre-graduation courses of public universities where tuition is very low or completely free in most countries. However exceptions may be found in some countries such as Chile. But as a rule, in the post-graduation courses (Masters, PhDs, and certain specialisations) tuition must be paid by the students even for public universities. Most (i.e. 60\%) of the total regional enrolment in higher education is concentrated in three countries: Brazil, Mexico and Argentina; the 
three most populous. Post-graduate taught and research courses offered by public higher education in Latin America and the Caribbean have traditionally had great popularity. Mexico and Brazil have an enrolment of over 100,000 students in post-graduate courses (Gazzola, 2008). However, the proportion of national populations with low incomes and limited social capital tends to be excluded from tertiary education. They studied in schools of low quality, thereby preventing them from gaining sufficiently high grades in the admission examinations. It is these sectors of the populations that form the market of the private universities of minor quality (Castro, 2004). For year 2008, in Brazil, $74 \%$ of the pupils who are registered in the universities belong to the highest quintile, and only $4 \%$ to the lowest. The percentage distribution of pupils from the highest quintile versus the lowest in Mexico, Chile, and Ecuador was 58 to 6,65 to 8 , and 42 to 6 respectively (CEPAL, 2008)

The model of financing prevalent in the region is a historical-negotiated one. However, new formulas of financing have been introduced (especially in Mexico, Chile, and Argentina) by linking results to the allocation of resources. The governments of some countries - such as Uruguay have introduced solidarity funds to give more opportunities to the most economically disadvantaged students with academic merit and potential.

Another trend is that the region has attracted foreign universities and other tertiary institutions, with both profit and non-profit orientation. We are witnessing a rapid increase in foreign institutions of higher education, hailing from the USA and Europe, both of which are offering a range of diverse modalities: distance education, units decentralised from headquarters, alliances, and agreements (The Economist, 2005). In many cases they do not have any baseline quality control procedure, or may even violate national regulations even though these are very modest concerning transnational higher education.

At the same time, the internationalisation of higher education has also presented itself in this region through intercontinental programmes such as ALFA (i.e. a programme of co-operation between higher education institutions of the European Union and Latin America and COLOMBUS (i.e. the Collaboration in University Management: a bridge between Universities and Scholars in Latin America and Europe); sub-regional programmes such as the Andres Bello Agreement and the Montevideo Group Association of Universities (AUGM) for the sub regional bloc MERCOSUR; Ibero-American networks and regional agencies. There are various programmes of different national and institutional networks, from the region and worldwide, giving various kinds of funds and scholarships to Latin America and Caribbean (LAC) professors and students. (Didou, 2005, p.133; CINDA, 2007). However, in 2004 LAC received only around 365,000 foreign students -1.5 percent of the 2.45 million registered worldwide - which indicates that the universities of the region do not constitute attractive destinations for international student flow in general. Nowadays, none of the Latin-American countries appears in the list of twenty-three destinations that attract major number of foreign students (UNESCO Institute for Statistics, 2007).

Of the 14 countries within the region, a total of 31 institutions grant educational credits totalling over US\$ 400 million in 2002 (García-Guadilla, 2006). Among these institutions, The Federal Caixa Económica of Brazil covers half of this amount. The Colombian Institute for Education Credit and Technical Studies Abroad (ICETEX) and the Fundación Gran Mariscal de Ayacucho (Fundayacucho) of Venezuela have similar programmes. In addition to the US\$ 400 million mentioned above, Cuba grants thousands of scholarships to students of the region and finances a Latin-American School of Medicine.

Privatisation of higher education in Latin America and the Caribbean has led to diversification within the tertiary sector, and in many cases to the decline of quality. In order to solve this problem, since the 1990s almost all the countries of the region have created organisations of accreditation. That is, the National Commission for the Evaluation of $\mathrm{HE}$ and the Council for the Accreditation of HE (Mexico); the HE Council (Chile); the National Council of Accreditation (Colombia); the National Commission of Evaluation and University Accreditation (Argentina); and the Central American System of Evaluation and Accreditation of HE (Central America). While in Brazil, there are the Coordination 
for the Improvement of Higher Education Personnel (CAPES) and the Experimental Mechanism of Accreditation of Careers for the Recognition of Titles of University Degree (MEXA/MERCOSUR) (Sobrinho, 2006). In some cases further legal sanctions have been employed to bring in, for example, a general education law for all sectors.

Of special interest to the higher education sector in this region is the Project $6 \times 4$ that Columbus has been preparing in the National Centre for Evaluation for Quality Education (CENEVAL) in Mexico. This is a pilot project with the aim of building a Latin-American common space of higher education, bearing the Bologna's European experience in mind (Sobrinho, 2006, p. 219). Of course there has long been a model of higher education in the smaller counties of the Central American region, especially in Costa Rica where the first university was founded in 1842 (Aguilar, 1990), and the regional organisation CSUCA, founded in 1948. CSUCA is a non-profit public Central American regional integrated organisation with 19 public university members from the (8) countries: Belize, Costa Rica, Dominican Republic, El Salvador, Guatemala, Honduras, Nicaragua, and Panama. Together they form the Central America Integrated System (SICA) as a strong counterpoint to the irregular and unregulated plethora of private universities (SICA, 2014).

\section{The Commonwealth Caribbean}

The Commonwealth Caribbean comprises the predominantly Anglophone islands bounded by the Gulf of Mexico and the Caribbean Sea, plus the two land based nations of Belize and Guyana and nearby Atlantic island nations and territories such as Barbados, the Bahamas and the Turks and Caicos islands (Thomas, 2014). Formerly part of the British Empire, almost all are now independent nations, but some are still in effect still colonies, officially known as British Overseas Territories. These include the aforementioned Turks and Caicos, plus the Caiman Islands, British Virgin Islands, Montserrat and Anguilla.

In the Commonwealth Caribbean, the University of the West Indies (UWI) was established as far back as 1948. It is the principal institution of HE in the Anglophone Caribbean. It has campuses in three countries: Jamaica, where the major headquarters is located, Trinidad and Tobago, and Barbados, plus numerous outposts in smaller islands. Guyana decided to create its own university. UWI receives nearly 20,000 students from 17 countries in the zone. If the distance HE applicants are also considered, then the total matriculation amounts to over 23,000 students. The rate of enrolment (GER) of the relevant age group differs from country to country: $19 \%$ in Jamaica, and $12 \%$ in Trinidad and Tobago (UNESCO Institute for Statistics, 2007). According to Trow's (2005) definition, in the Anglophone Caribbean HE are regarded differently, in Jamaica it is considered "mass" HE, whereas in others, such as Trinidad and Tobago, it is considered "elitist". But it is not considered universal in any of the countries with the possible exception of the British Virgin Islands, whose inhabitants have the additional option of attending the nearby University of the Virgin Islands in St John, the largest of the US Virgin Islands.

Two significant trends have been evident in the Commonwealth Caribbean in recent decades. One is the same as in Latin America in the form of the creation of private universities. The most notable, and now well established, is St George's University in Grenada, an initiative from the USA that was implicated in the American bombing of Grenada in 1983 (Brock, 1985; 2012). The other is the upgrading of previously separate tertiary institutions, such as teachers colleges and technical colleges, to form unified institutions often providing the first years of undergraduate study recognised by the University of West Indies. A good example is Sir Arthur Lewis Community College in Saint Lucia (Brock, 2008)

\section{Conclusion}

Despite the increase of tertiary enrolment in Latin America, the average budget in the countries of the region allocated for higher education is lower than 1.5\% of the Gross Domestic Product (GDP) 
(García-Guadilla, 2006). This is clearly insufficient to satisfy the needs of a region going through rapid economic development with a need for high quality labour. It is also insufficient to provide for the relevant social research and development needs of universities. Indeed, the average investment in science and technology of the countries within the region is $0.72 \%$ of the GDP (Garcia-Guadilla, 2006).

The World Council of Higher Education (WCHE) in Paris in 1998, and its follow-up meetings, offered a theoretical framework for the transformation of higher education. This had some impact in Latin America and the Caribbean by building on what had been expressed in the Regional Conference of LAC (1996) and in its Action Plan. This implied a shared general vision about how to carry out the transformation processes of the $\mathrm{HEI}$ - both public and private - through institutional evaluation, with the goal of improving the management and financial systems as well as equity in access as a key priority. By extension, the university should be a key agent in transforming society, building viable alternatives in the midst of complexity and uncertainty. International cooperation and the building of networks has been one of the greatest inputs of the WCHE in the region. With it came innovation and a degree of internationalisation of higher education. The UNESCO International Institute for Higher Education in Latin America and the Caribbean (UNESCO IESALC) has played a leading role in this sense, as an alternative and a counter balance of the restrictive structural adjustment agenda of the World Bank in the 1990s. The World Bank had, at that time, considered the only useful investment in education to be in basic education, and thereby inadvertently stimulated the problematic privatisation of higher education as solution to increasing access. As a result, despite its rapid improvement in comparison with developed countries, the main challenges facing higher education today in Latin America and the Caribbean are: a) the rapid increase of privatisation; $b$ ) insufficient public funding; c) lack of access for the poorest; and (d) the low general enrolment rate (Didriksson, 2008; Sanyal and López Segrera, 2008).

Universities and higher education systems in developed countries are in an advantageous position, given the greater availability of financial resources, their state-of the-art research programmes, and their privileged access to information networks. Nevertheless, HEls in LAC can enrich themselves through various forms of cooperation without subjected in any way. There has been a regression from the original coexistence-model centred on the learning subject and the student, to an authoritarian model centred on the teaching subject and the administrative subject. Concurrently, strong trends such as the process triggered by the Bologna Declaration (1999), which aim to rectify practices that oppose the original ideal of coexistence, are also rising. In LAC, there is a growing debate about the possibilities of an Ibero-American area of $\mathrm{HE}$, based on Bologna.

In order to lead the way of change and innovation in LAC, to reinvent the university, and achieve its permanent self-reform, it is necessary to have the political will to change; a solid institutional project; widely available information on the university in the different regions and countries; and knowledge about the relevant experiences of university transformation elsewhere. Research and graduate courses must serve, in the first place, the demands of society and not those of corporate or market interests exclusively. These things lie at the heart of the Bologna Process that is itself proving to be a long and contested phenomenon.

The virtualisation of education is increasing but is not cheap. Technology offers great possibilities for inter-university cooperation in LAC, but these have been used in the academic environment, to a large extent, by the new providers who offer transnational higher education with lucrative profitoriented aims. By contrast, in the Commonwealth Caribbean, the virtual dimension is much more affordable and accessible through the twin agencies of the Commonwealth of Learning (COL) and the Virtual University of Small States which is related to the COL.

Universities are traditional hubs for teaching, research, and serving the local community. However, the weakness of universities worldwide is in their lack of service to society in its local and regional dimensions. UNESCO has been working in this region with the objective of transforming the university and to reinvent HEls, adapting them to meet the demands of a modern knowledge society. This is an issue not limited to the Latin American and Caribbean regions, but one that needs serious attention. 
The first recommendation for meaningful reform is to begin treating higher education as a means for public service, meant for public good, regardless of the institution's source of funding. This implies that public as well as private higher education institutions in LAC should assume a public commitment with society. Access should be "equal for all according to their respective merits" as stated in article 26.1 of the Universal Declaration of Human Rights (UN, 1948). This was, and is, a global aspiration for which some examples from elsewhere could be informative. Is the European space of higher education Bologna going in this direction? If so, does it have lessons, or even encouragement for Latin America and the Caribbean? Already networks of HE in that region, such as the Central American University Superior Council (CSUCA), is playing an important role.

Despite the aforementioned spectre of GATS, the internationalisation of higher education remains comprehensive. New concepts such as "cross-border higher education" and "trade in education" are fast developing, but as of now, have a prime commercial purpose aimed at obtaining maximum profits from higher education. In LAC, the process of internationalisation of higher education needs to be preserved through proper regulation and accreditation to avoid its displacement or substitution by profiteering internationalisation. This means, establishing regulations by mutual agreement across all countries of the region. Perhaps an autonomous Latin American and Caribbean Regional University, a kind of 'super CSUCA' could fulfil the social function which society needs, not only in terms of equality in access, but also in terms of the state-of-the-art delivery with regards to knowledge, information, and proposals for future human well-being and survival in the problematic $21^{\text {st }}$ century. This would not mean evading the legislation applicable to HEI in LAC or lacking accountability in the eyes of society about the use of public resources at the HEl's disposal, given to them in order to achieve their academic task. It would, however, include helping to improve the primary and secondary education levels in the region. This must be part of the aspiration of any region, to improve its tertiary education.

Nationalism is not the answer but nations are still the prime political parameter. Can we, and especially the universities of Latin America and the Caribbean, manage to educate our public officials and the society in general, for the common good and sustainable survival?

\section{Notes}

1 Part of this paper is published in López Segrera, F. (2010) El impacto de la crisis económica global en la Educación Superior Mundial y Regional. Educación Superior y Sociedad. 15(1). Caracas: IESALC UNESCO.

\section{References}

Aguilar, P (1990). The Evolution of the Costa Rican Education Profile. In C. Brock and D. Clarkson (Eds.) Education in Central America and the Caribbean. London: Routledge, pp 257-278.

Alexiadou, N. and Brock, C. (1999). Education as a Commodity. Great Glemham: John Catt Educational Ltd.

Altbach, P. (2004). The Cost and Benefits of World Class Universities. Available at: http://www. universite-toplum.org/summary.php3?id=182. [Accessed 21 December 2014].

Altbach, P. (2006). International Higher Education - reflections on policy and practice. Boston: Boston College CIHE.

Brock, C. (1985). 'Culture and Identity in Grenadian Education'. In C. Brock and W. Tulasiewic (Eds), Cultural Identity and Educational Policy. London: Croom Helm, pp 69-91.

Brock, C. (2007). Historical and Societal Roots of Higher Education for Quality Assurance. In GUNI Higher Education in the World 2007: Accreditation for Quality Assurance: What is at Stake?. Basingstoke: Palgrave Macmillan, pp 24-36.

Brock, C. (2008). Perspectivas de la Educacion Superior en la Caribe Anglofono. In F. Segrera, C. Brock and J. Sobrinho (Eds.), La Educaoaion Superior en America Latina y El Caribe. Sorocaba: Avalicao, pp 391-424. 
Brock, C. (2009). Perspectives on Higher Education in the Commonwealth Caribbean. In F. LopezSegrera, C. Brock and J.D. Sobrinho (Eds.), Higher Education in Latin America and the Caribbean 2008. Caracas: IESALC/UNESCO, pp 93-112.

Brock, C. (2012). Universities, Independence, Internationalism and Integrity. In Duran and F. LopezSegrera, (Eds.), La Internacionalizacion de la Educacion Superior a Nivel Mundial y Regional. Bogota: Universidad Catolica de Colombia/Planeta, pp 49-62.

Brock, C, Howard, C, and Mason, G. (2012). 'Grenada, An Overview'. In E. Thomas (Ed.), Education in the Commonwealth Caribbean and Netherlands Antilles. London: Bloomsbury, pp 183-198.

Brunner, J. J. (2005). Tendencias recientes de la educación superior a nivel internacional. Available at http://mt.educarchile.cl. [Accessed 14 February 2015 ]

Castro, M.H.M. (2004). The State and the Market in the Regulation of Higher Education in Brazil. In C. Brock and S. Schwartzman (Eds.), The Challenges of Education in Brazil. Wallingford: Symposium Books, pp 179-208.

CEPAL (2008). Panorama Social de América Latina 2008. Santiago, Chile: ECLAC

CINDA (2007). Educación superior en Iberoamérica. Informe 2007. Santiago, Chile: CINDA.

Didou, S. (2005). Internacionalización y proveedores externos de educación superior en América Latina y el Caribe. Mexico D.F.: ANUIES.

Didriksson, A. (2008). The Role of Higher Education for Human and Social Development in Latin America and the Caribbean. In GUNI. Higher Education in the World 3. New York: Palgrave Macmillan.

Fernandez Lamarra, N. (2008). Una perspeciva comparada de la educación superior en América Latina. Paper presented at the University of Havana, 2008.

García-Guadilla, C. (2006). Financing Higher Education in Latin America. In GUNI: Higher Education in the World 2006. New York: Palgrave Macmillan.

Gazzola, A. L. (2008). Integración académica e internacionalización de la educación superior. Paper presented at the University of Havana, 2008.

Sanyal, B.C. \& Lopez-Segrera, F. (2008). An Overview of Regional Perspectives on the Role of Higher Education in Social and Human Development. In GUNI, Higher Education in the World3. New York: Palgrave Macmillan.

Mollis, M. (2003). Las universidades en América Latina: ¿reformadas o alteradas? Buenos Aires: CLACSO.

Ordorika, I. (2008). Contemporary Challenges for Public Research Universities. In GUNI. Higher Education in the World 3. New York: Palgrave Macmillan.

Pillay, P. (2010). Higher Education Financing in East and Southern Africa. Somerset West, SA: CHET.

Sauve, P. (2002). Trade, Education and the GATS: What's In, What's Out, What's All the Fuss About? Paper presented at the OECD/US Forum on Trade in Educational Services Washington, DC, USA.

SICA (2014). SICA Member States. Available at: http://www.sica.int/miembros/miembros_en.aspx. [Accessed 18 June 2014].

Sobrinho, D.J. (2006). Acreditación de la educación superior en América Latina y el Caribe. In GUNI. La Educación Superior en el Mundo 2007. Madrid-Barcelona-México: Mundi-Prensa.

The Economist (2005). The Brain Business. A Survey of Higher Education. 10 September 2005.

Thomas, E. (2014). Education in the Commonwealth Caribbean and the Netherlands Antilles. London: Bloomsbury.

Trow, M. (2005). Reflections on the Transition from Elite to Mass to Universal Access: Forms and Phases of Higher Education in Modern Societies since WWII. In P. Altbach (Ed.) International Handbook of Higher Education. Dordrecht: Kluwer Academic Publishers, pp.243-280.

UNESCO IESALC (2006). Informe sobre la Educación Superior en América Latina y el Caribe 20002005. Caracas: UNESCO.

UNESCO (2009). World Conference on Higher Education: The New Dynamics of Higher Education and Research for Societal Change and Development. Paris: UNESCO.

UNESCO Institute of Statistics (2003). Global Education Digest. Montreal: UIS 
UNESCO Institute of Statistics (2007): Global Education Digest. Montreal: UIS UNESCO Institute of Statistics (2009): Global Education Digest. Montreal: UIS UNESCO Institute of Statistics (2011). Global Education Digest. Montreal: UIS. UNESCO Institute of Statistics (2014). Global Education Digest. Montreal: UIS.

United Nations (1948). Universal Declaration of Human Rights. Available at: http://www.un.org/ rights/50/decla.htm. [Accessed 18 June 2014]. 